Section Editor

Mitchell S.V. Elkind, MD, MS

\title{
Teaching NeuroImages: \\ Striatocapsular infarct presumed due to intracranial lipoma
}

Fahri Halit Besir, MD

Omer Onbas, MD

Correspondence to

Dr. Besir:

drfhbesir@gmail.com

Download teaching slides: Neurology.org
A 27-year-old woman with no known risk factors for stroke presented with right hemiparesis. There was infarction of left corpus striatum on brain CT and MRI (figure 1). Imaging also showed an intracranial lipoma adjacent to the middle cerebral artery (MCA) (figure 2).

We presumed that striatocapsular infarction was due to occlusion of the orifice of a lenticulostriate artery originating from the MCA. ${ }^{1}$ Intracranial lipomas may rarely occur adjacent to the MCA and may be associated with striatocapsular infarction. ${ }^{2}$

\section{AUTHOR CONTRIBUTIONS}

F.H. Besir: corresponding author who sees the cases first and performed the literature search. O. Onbas: consultant doctor of the Radiology Department.

\section{STUDY FUNDING}

No targeted funding reported.

\section{REFERENCES}

1. van Overbeek EC, Knottnerus IL, van Oostenbrugge RJ. Disappearing hyperdense middle cerebral artery sign is associated with striatocapsular infarcts on follow-up CT in ischemic stroke patients treated with intravenous thrombolysis. Cerebrovasc Dis 2010;30:285-289.

2. Yildiz H, Hakyemez B, Koroglu M, Yesildag A, Baykal B. Intracranial lipomas: importance of localization. Neuroradiology 2006;48:1-7.

Figure 1 Striatocapsular infarction on the left side
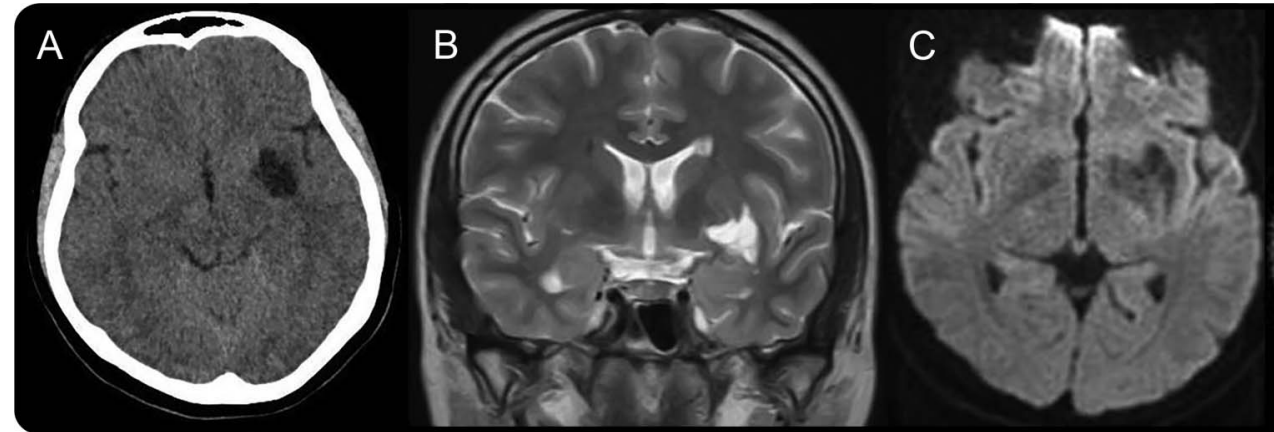

D

(A) Brain CT images, (B) MRI T2-weighted images, (C) diffusion-weighted images, and (D) apparent diffusion coefficient maps show chronic infarction

Figure 2 Intracranial lipoma (arrow) located adjacent to the middle cerebral artery bifurcation

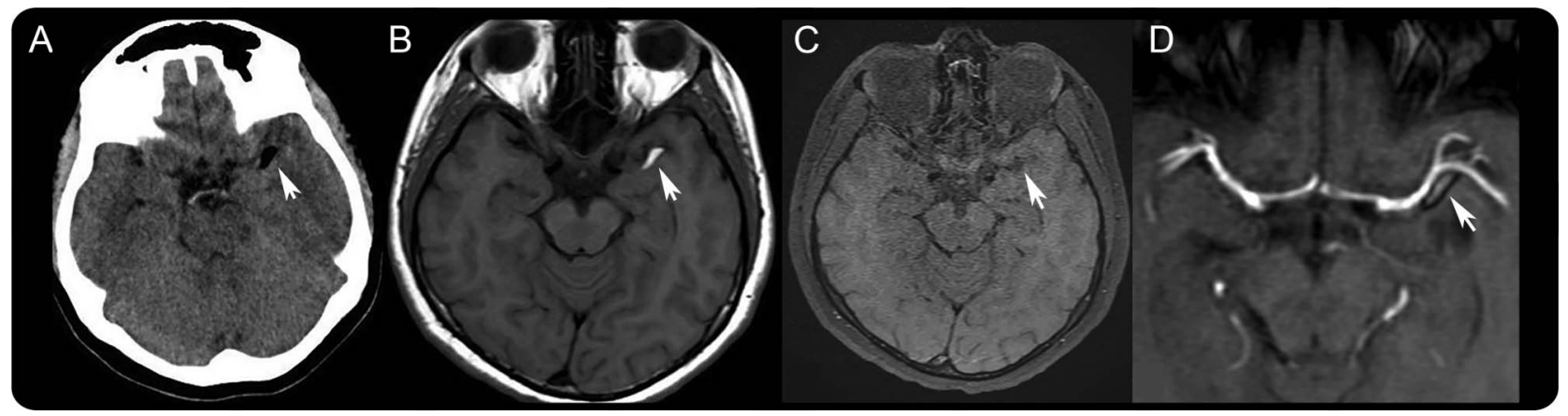

(A) The brain CT density of this hypodense lesion was measured as -80 HU. (B) T1-weighted MRI shows the hyperintense lipoma. (C) On T1-weighted image with fat suppression, intensity of the lesion is homogeneously decreased. (D) Reformatted time-of-flight magnetic resonance angiogram image shows lipoma caused chemical shift artifact at the origin of the lenticulostriate arteries.

From the Department of Radiology, Duzce University Medicine School, Duzce, Turkey.

The authors report no disclosures relevant to the manuscript. Go to Neurology.org for full disclosures. 


\section{Neurology}

\section{Teaching NeuroImages: Striatocapsular infarct presumed due to intracranial lipoma Fahri Halit Besir and Omer Onbas \\ Neurology 2015;84; e11 \\ DOI 10.1212/WNL.0000000000001121}

This information is current as of January 12, 2015

Updated Information \&
Services

Supplementary Material

References

Subspecialty Collections

Permissions \& Licensing

Reprints including high resolution figures, can be found at:

http://n.neurology.org/content/84/2/e11.full

Supplementary material can be found at:

http://n.neurology.org/content/suppl/2015/01/10/WNL.0000000000001 121.DC1

This article cites 2 articles, 0 of which you can access for free at: http://n.neurology.org/content/84/2/e11.full\#ref-list-1

This article, along with others on similar topics, appears in the following collection(s):

CT

http://n.neurology.org/cgi/collection/ct

Infarction

http://n.neurology.org/cgi/collection/infarction

MRI

http://n.neurology.org/cgi/collection/mri

Information about reproducing this article in parts (figures,tables) or in its entirety can be found online at:

http://www.neurology.org/about/about_the_journal\#permissions

Information about ordering reprints can be found online:

http://n.neurology.org/subscribers/advertise

Neurology ${ }^{\circledR}$ is the official journal of the American Academy of Neurology. Published continuously since 1951 , it is now a weekly with 48 issues per year. Copyright @ 2015 American Academy of Neurology. All rights reserved. Print ISSN: 0028-3878. Online ISSN: 1526-632X.

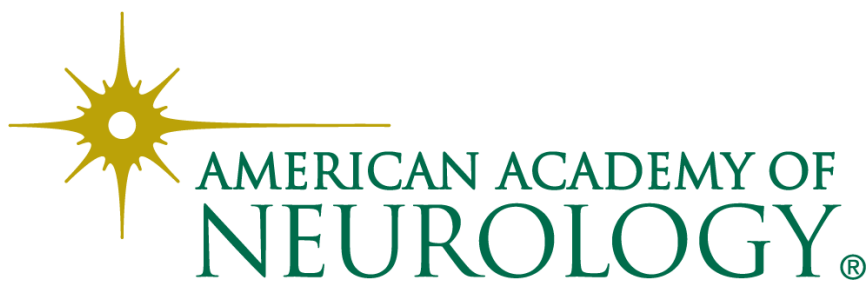

